University of Nebraska - Lincoln

DigitalCommons@University of Nebraska - Lincoln

Nutrient Reserves of Lesser Scaup (Aythya affinis) During Spring

Migration in the Mississippi Flyway: A Test of the Spring Condition Hypothesis

\author{
Michael Anteau \\ Louisiana State University, Baton Rouge, manteau@usgs.gov \\ Alan Afton \\ U.S. Geological Survey
}

Follow this and additional works at: https://digitalcommons.unl.edu/usgsnpwrc

Part of the Other International and Area Studies Commons

Anteau, Michael and Afton, Alan, "Nutrient Reserves of Lesser Scaup (Aythya affinis) During Spring Migration in the Mississippi Flyway: A Test of the Spring Condition Hypothesis" (2004). USGS Northern Prairie Wildlife Research Center. 14.

https://digitalcommons.unl.edu/usgsnpwrc/14

This Article is brought to you for free and open access by the US Geological Survey at DigitalCommons@University of Nebraska - Lincoln. It has been accepted for inclusion in USGS Northern Prairie Wildlife Research Center by an authorized administrator of DigitalCommons@University of Nebraska - Lincoln. 


\title{
NUTRIENT RESERVES OF LESSER SCAUP (AYTHYA AFFINIS) DURING SPRING MIGRATION IN THE MISSISSIPPI FLYWAY: A TEST OF THE SPRING CONDITION HYPOTHESIS
}

\author{
Michael J. Anteau ${ }^{1,3}$ and Alan D. Afton ${ }^{2}$ \\ ${ }^{1}$ School of Renewable Natural Resources, Louisiana State University, Baton Rouge, Louisiana 70803, USA; and \\ ${ }^{2}$ U.S. Geological Survey, Louisiana Cooperative Fish and Wildlife Research Unit, Louisiana State University, \\ Baton Rouge, Louisiana 70803, USA
}

\begin{abstract}
Aвstract. - The continental scaup population (Lesser [Aythya affinis] and Greater [A. marila] combined) has declined markedly since 1978. One hypothesis for the population decline states that reproductive success has decreased because female scaup are arriving on breeding areas in poorer body condition than they did historically (i.e. spring condition hypothesis). We tested one aspect of that hypothesis by comparing body mass and nutrient reserves (lipid, protein, and mineral) of Lesser Scaup at four locations (Louisiana, Illinois, Minnesota, and Manitoba) between the $1980 \mathrm{~s}$ and 2000s. We found that mean body mass and lipid and mineral reserves of females were 80.0, 52.5, and $3.0 \mathrm{~g}$ higher, respectively, in the 2000s than in the 1980s in Louisiana; similarly, body mass and lipid and mineral reserves of males were 108.8, 72.5, and $2.5 \mathrm{~g}$ higher, respectively. In Illinois, mean body mass and lipid reserves of females were 88.6 and $56.5 \mathrm{~g}$ higher, respectively, in the 2000s than in the 1980s; similarly, body mass and lipid and mineral reserves of males were 80.6, 76.0, and $2.7 \mathrm{~g}$ higher, respectively. Mean body mass of females were 58.5 and $58.9 \mathrm{~g}$ lower in the 2000s than in the 1980s in Minnesota and Manitoba, respectively; mean body mass of males, similarly, were $40.7 \mathrm{~g}$ lower in Minnesota. Mean lipid reserves of females in the 2000s were 28.8 and $27.8 \mathrm{~g}$ lower than those in the 1980s in Minnesota and Manitoba, respectively. Mean mineral reserves of females in the 2000s were $3.2 \mathrm{~g}$ lower than those in the 1980s in Manitoba. Consequently, females arriving to breed in Manitoba in the 2000s had accumulated lipid reserves for 4.1 fewer eggs and mineral reserves for 0.8 fewer eggs than those arriving to breed there in the 1980s. Accordingly, our results are consistent with the spring condition hypothesis and suggest that female body condition has declined, as reflected by decreases in body mass, lipids, and mineral reserves that could cause reductions in reproductive success and ultimately a population decline. Received 8 August 2003, accepted 29 March 2004.
\end{abstract}

Resumen.-La población continental de patos del género Aythya (A. affinis y A. marila) ha disminuido marcadamente desde 1978; una hipótesis plantea que el éxito reproductivo ha disminuido porque las hembras de Aythya están llegando a las áreas reproductivas en peores condiciones corporales que históricamente (i.e. hipótesis de la condición de primavera). Evaluamos un aspecto de esta hipótesis comparando el peso corporal y las reservas de nutrientes (lípidos, proteínas y minerales) de A. affinis en cuatro localidades (Louisiana, Illinois, Minnesota y Manitoba) en las décadas de los años 1980 y 2000. Encontramos que el peso corporal promedio y las reservas de lípidos y minerales de las hembras fueron 80.0, 52.5 y $3.0 \mathrm{~g}$ mayores, respectivamente, en la década del 2000 que en la de 1980 en Louisiana; de modo similar, el peso corporal y las reservas de lípidos y minerales de los machos fueron 108.8, 72.5 y $2.5 \mathrm{~g}$ mayores, respectivamente. En Illinois el peso corporal promedio y las reservas de lípidos de las hembras fueron 88.6 y $56.5 \mathrm{~g}$ mayores, respectivamente, en la década del 2000 que en la de 1980; de modo similar, el peso corporal y las reservas de lípidos y minerales de los machos fueron 80.6, 76.0 y $2.7 \mathrm{~g}$ mayores, respectivamente. Los pesos corporales promedio de las hembras fueron 58.5 y $58.9 \mathrm{~g}$ menores en la década del 2000 que en la de 1980 en Minnesota y Manitoba, respectivamente; similarmente, el peso corporal promedio de los machos fue $40.7 \mathrm{~g}$ menor en Minnesota. Las reservas de lípidos promedio de las hembras en la década del 2000 fueron 28.8 y 27.8 g menores que aquellas en la década de 1980 en Minnesota y Manitoba, respectivamente. La reserva de minerales promedio de las hembras en la década del 2000 fue 3.2 g menor que aquella de la década de 1980 en Manitoba. Consecuentemente, las hembras que llegaron a criar a Manitoba en la década del 2000 habían acumulado reservas lipídicas para 4.1 huevos menos y reservas minerales para 0.8 huevos menos

${ }^{3}$ E-mail: mantea1@1su.edu 
que aquellas que llegaron a criar allí en la década de 1980. Nuestros resultados son consistentes con la hipótesis de la condición de primavera y sugieren que la condición corporal de las hembras ha empeorado, como lo muestran las reducciones en el peso corporal y en las reservas de lípidos y minerales. Esto puede ocasionar reducciones en el éxito reproductivo y en última instancia un descenso de las poblaciones.

The CONTINENTAL SCAUP population-Lesser (Aythya affinis) and Greater (A. marila) scaup combined - has declined markedly since 1978 (Austin et al. 1998, Afton and Anderson 2001, Wilkins and Otto 2003). The scaup decline is of particular concern in the Mississippi Flyway where, on average, $40 \%$ of the continental scaup population winters (Afton and Anderson 2001). Afton and Anderson (2001) reported that the decline in the continental scaup population is likely driven by a decline in the Lesser Scaup population. Recruitment of Lesser Scaup in the Mississippi Flyway apparently declined from 1978 to 1997, and female survival rates declined relative to that of males (Afton and Anderson 2001).

Nutrient reserves acquired during winter or spring migration (or both) are important determinants of reproductive success in geese and some ducks (Ryder 1970, Afton and Ankney 1991, Alisauskas and Ankney 1992). Lesser Scaup use endogenous and exogenous nutrients for clutch formation and incubation (Afton and Ankney 1991, Afton and Paulus 1992, Esler et al. 2001). In Manitoba, lipid reserves of female Lesser Scaup decline an average of $0.5 \mathrm{~g}$ for every gram of lipid deposited in eggs, and mineral reserves decline $0.1 \mathrm{~g}$ for every gram of eggshell produced (Afton and Ankney 1991). In a recent combined analysis of Lesser Scaup breeding in Manitoba and Alaska, Esler et al. (2001) reported that lipid and mineral reserves decline, on average, 0.7 and $0.1 \mathrm{~g}$, respectively, for every gram of that nutrient allocated to eggs. Protein reserves changed little during egg formation in Lesser Scaup nesting in Manitoba and Alaska (Afton and Ankney 1991, Esler et al. 2001). Thus, lipids are seemingly the most important nutrient reserves for female Lesser Scaup on arrival at breeding areas.

Declines in body mass may result in decreased survival or reproductive success (or both), especially in females (Afton and Ankney 1991, Pace and Afton 1999). Austin et al. (2000) and Afton and Anderson (2001) outlined several hypotheses explaining the scaup population decline. The spring condition hypothesis states that reproductive success of Lesser Scaup has declined because females are arriving on breeding areas in poorer body condition than in the past, because reduced food resources are preventing females from acquiring sufficient nutrient reserves on wintering, spring migration, or breeding areas (or on all three) (Afton and Anderson 2001). If female Lesser Scaup are currently arriving on breeding areas in poor body condition, they may have to spend more time feeding on breeding areas prior to laying eggs (see Afton and Anderson 2001) because of their reliance on nutrient reserves for egg production and incubation (Afton and Ankney 1991, Afton and Paulus 1992, Esler et al. 2001). Moreover, if females currently initiate nesting later than females have historically, they would likely produce fewer young because of the general negative correlation between nest initiation date and reproductive performance among waterfowl (Rohwer 1992).

We tested one aspect of the spring condition hypothesis - whether there has been a decrease in body condition of Lesser Scaup during spring migration-by comparing body mass and nutrient reserves (lipid, protein, and mineral) between two decades (1980s and 2000s) at the same locations in Louisiana, Illinois, Minnesota, and Manitoba. We analyzed body mass to allow comparisons with other studies for which nutrient-reserve data were not available.

\section{Methods}

Study areas. - We used band-recovery data, sightings of color-marked ducks, and historical accounts to select collection locations that were important stopover areas for Lesser Scaup on a contiguous migration path within the Mississippi Flyway (Thompson 1973, Afton and Hier 1985, Afton et al. 1991, Havera 1999, Pace and Afton 1999). We collected Lesser Scaup (hereafter "scaup") during the 1980s and 2000s at four locations (Table 1): (1) southern Louisiana (hereafter "Louisiana"; see below); (2) pool 19 of the Mississippi River between Hamilton and Niota, Illinois (hereafter "Illinois"); (3) northwestern Minnesota (hereafter "Minnesota"; including collection sites at Thief Lake Wildlife Management Area, Agassiz National Wildlife Refuge, and Roseau River Wildlife Management 
TABLE 1. Decades, locations, years, dates, and numbers of male and female Lesser Scaup collected during winter and spring migration in the Mississippi Flyway.

\begin{tabular}{|c|c|c|c|c|c|}
\hline Decade & Location & Year & Dates & Males & Females \\
\hline \multirow[t]{9}{*}{$1980 \mathrm{~s}$} & Southern Louisiana ${ }^{a}$ & 1986 & 14-24 January & 42 & 33 \\
\hline & Illinois & 1986 & 16-30 March & 22 & 22 \\
\hline & Northwestern Minnesota & 1986 & 17 April-1 May & 31 & 26 \\
\hline & & 1987 & 17-30 April & 9 & 9 \\
\hline & & 1988 & 14-24 April & 27 & 34 \\
\hline & Erickson, Manitoba ${ }^{b}$ & 1977 & 13 May-1 June & 3 & 4 \\
\hline & & 1978 & 13-25 May & 3 & 3 \\
\hline & & 1979 & 7 May & 0 & 1 \\
\hline & & 1980 & 7 May-23 June ${ }^{c}$ & 9 & 7 \\
\hline \multirow[t]{7}{*}{ 2000s } & Southern Louisiana ${ }^{d}$ & 2000 & 12 February-4 March & 34 & 45 \\
\hline & Illinois & 2000 & 13-15 March & 40 & 40 \\
\hline & & 2001 & 14-17 March & 30 & 29 \\
\hline & Northwestern Minnesota & 2000 & 10-25 April & 40 & 40 \\
\hline & & 2001 & 27 April-3 May & 30 & 30 \\
\hline & Erickson, Manitoba & 2000 & 30 April-15 May & 40 & 39 \\
\hline & & 2001 & 6-15 May & 30 & 34 \\
\hline Total & & & & 390 & 396 \\
\hline
\end{tabular}

a Specimens collected from Rockefeller State Wildlife Refuge (Afton et al. 1989).

${ }^{\mathrm{b}}$ Data from Afton and Ankney 1991 (pre-rapid follicle growth samples only).

c $75 \%$ of birds collected between 7 May and 6 June.

d Specimens collected from Lake Pelto (south of Cocodrie, Louisiana)

Area); and (4) a Prairie Parkland breeding area west of Erickson, Manitoba (hereafter "Manitoba"; between Sandy Lake and Elphinstone, Manitoba, and the area $35 \mathrm{~km}$ south of those towns). Detailed descriptions of locations are provided by Rogers (1964), Thompson (1973), Hohman (1985), Afton et al. (1989), and Pace and Afton (1999).

Historical body-mass and nutrient-reserve data from Louisiana (Afton et al. 1989) were collected at Rockefeller State Wildlife Refuge; however, we observed few scaup on that area in 2000. Thus, we conducted the 2000 Louisiana collections near Lake Pelto, south of Cocodrie, Louisiana $(165 \mathrm{~km}$ east of Rockefeller State Wildlife Refuge), where large numbers of scaup were using saline coastal fringe marsh composed mostly of smooth cord grass (Spartina alterniflora).

Collection of specimens. - We collected scaup with a shotgun by sneaking or spotlighting at night to avoid potential collection biases associated with using decoys or baiting (Pace and Afton 1999). We determined pair status of individuals prior to collection using criteria outlined in Afton (1985). In Louisiana, we collected scaup just prior to spring migration. We conducted collections in Illinois and Minnesota during the middle of migration, coinciding with relatively large numbers of scaup using those spring stopover areas (Table 1). We initiated collections in Manitoba when resident scaup first arrived and began using small ponds (see below), and concluded before the start of rapid follicle growth (RFG) in females (Table 1).

In Louisiana and Illinois, we collected scaup from actively foraging or roosting flocks consisting of five or more scaup. We limited collections in Minnesota and Manitoba to paired individuals, except for 26 unpaired males that were collected in Minnesota in 1986 and 1987. We included those 26 males in our analyses because body mass and lipid, protein, and mineral reserves did not differ between paired and unpaired males in 1986 (analyses of variance or covariance, $P=$ $0.10, P=0.37, P=0.48$, and $P=0.35$, respectively; too few specimens were collected in 1987 to test for pairing effect; Table 1). We further limited collections in Manitoba to isolated pairs on smaller ponds, which, judging from observations of marked individuals, ensured a sample of resident breeders (A. D. Afton unpubl. data; R. G. Clark pers. comm.).

Specimen dissections and body-composition analyses.We recorded body mass of scaup immediately upon collection $( \pm 1 \mathrm{~g})$. Specimens were then labeled, placed in double plastic bags, frozen, and transported to the laboratory for dissections. In the laboratory, we thawed specimens and took the following morphometrics: (1) total length $( \pm 1 \mathrm{~mm})$, from tip of longest rectrix to tip of bill, with bird stretched on its back (Afton and Ankney 1991); (2) wing length $( \pm 1 \mathrm{~mm}$; Carney 1992); and (3) rectrix length $( \pm 1 \mathrm{~mm})$, from body to tip of longest rectrix.

We conducted dissections as described in Afton et al. (1989) and Afton and Ankney (1991). Specimens collected in the 1980s were prepared for bodycomposition analysis as described in Afton et al. (1989) and Afton and Ankney (1991). The 2000 and 2001 specimens were ground in a bowl chopper and grinder (Hobart model 84145, Troy, Ohio). Samples were chopped in the bowl chopper for $\sim 8 \mathrm{~min}$, then 
passed twice through the grinder attachment using 10- and 5-mm plates, respectively. Samples were then thoroughly mixed, and a subsample of $\sim 150 \mathrm{~g}$ was weighed and dried to a constant mass at $80^{\circ} \mathrm{C}$ and reweighed. The dry subsample was then reground in a coffee mill (Moulinex, Concord, Ontario) until it could pass through a 2-mm sieve. All body-composition analyses were contracted out to the University of Western Ontario and conducted as described in Afton and Ankney (1991).

We calculated nutrient-reserve levels using the following equations. To represent the sample on which body composition analyses were conducted, we calculated carcass dry mass (CDM) as

$$
\begin{aligned}
& \mathrm{CDM}_{1980 \mathrm{~s}}=(\mathrm{DM} / \mathrm{WM}) \mathrm{IFFBM}-\mathrm{AFM} \\
& \mathrm{CDM}_{2000 \mathrm{~s}}=(\mathrm{SDM} / \mathrm{SWM}) \mathrm{IFFBM}-\mathrm{AFM}
\end{aligned}
$$

where DM is dry mass (sum of all dried components of the carcass), WM is wet mass (sum of all wet components of the carcass), SDM is subsample dry mass, SWM is subsample wet mass, IFFBM is ingesta-free fresh-body mass, and AFM is abdominal fat mass removed, weighed, and discarded during dissections. We used a sampling method of calculating CDM rather than summing dried components of the carcass, for comparability between historical (1980s) and current data sets (2000s) and to account for small amounts of carcass lost in the dissection and grinding processes. Our estimates of lipid, protein, and mineral reserves (grams) were calculated as

$$
\begin{aligned}
& \text { PLipid }=\left(\mathrm{SDM}_{\mathrm{L}}-\mathrm{SLDM}_{\mathrm{L}}\right) / \mathrm{SDM}_{\mathrm{L}} \\
& \text { Lipid }=\text { PLipid }(\mathrm{CDM})+\mathrm{AFM} \\
& \mathrm{CLDM}=\mathrm{CDM}-\mathrm{PLipid}(\mathrm{CDM}) \\
& \text { Protein }=\left[\left(\mathrm{SLDM}_{\mathrm{c}}-\mathrm{ASH}\right) / \mathrm{SLDM}_{\mathrm{c}}\right] \text { CLDM } \\
& \text { Mineral }=\text { CLDM }- \text { Protein }
\end{aligned}
$$

where PLipid is the proportion of lipids, $\mathrm{SDM}_{\mathrm{L}}$ is sample dry mass before lipid extraction, $\operatorname{SLDM}_{L}$ is sample lean-dry mass after lipid extraction, CLDM is carcass lean-dry mass, $\mathrm{SLDM}_{\mathrm{c}}$ is the sample lean-dry mass remaining after transferred into the crucible for ashing in a muffle furnace, and ASH is the remains after ashing.

Statistical analyses. - We conducted separate analyses for each sex, because predictions of the spring condition hypothesis concern only females; thus, sex-specific estimates of least-squares means for body mass and nutrient reserves were required. For each sex, we conducted a principal-components analysis (PCA) of the correlation matrix for all morphometrics (PROC PRINCOMP; SAS Institute 1993). We then used the scores from first principal component (PC1) to index body size (Afton and Ankney 1991, Esler et al. 2001).

We created a variable named "collection day" to adjust for varying lengths of collection periods (Table
1), because body mass and nutrient reserves could change over time at a given location within years. We calculated collection day for Louisiana, Illinois, and Minnesota data sets by subtracting the Julian date of the first day of collections per location and year from the Julian date when the individual was collected and then adding one. For Manitoba data, we subtracted the Julian date of the first day that isolated pairs were observed on small wetlands from the Julian date when the individual was collected and then added one.

We compared body mass and nutrient reserves between two decades (historical [1980s] vs. current [2000s]; Table 1). For simplicity, samples collected in 1977-1980 (Afton and Ankney 1991) were included in the 1980s decade. For each sex and response variable (body mass, lipid, mineral, and protein), we conducted an analysis of covariance (ANCOVA; PROC MIXED; SAS Institute 1993), with decade and location as class variables and PC1 and collection day as covariates. We used restricted-residual maximumlikelihood estimation methods in all ANCOVAs (PROC MIXED; SAS Institute 1993). To control for annual variation, while testing for a difference between decades, we specified collection year within decade as a random term for all ANCOVAs (PROC MIXED; SAS Institute 1993). We used backwards elimination $(P$-values $\leq 0.05)$ with all possible interactions, excluding interactions with PC1, to select the final models (Zar 1996). We did not allow PC1 to interact with other variables, because those interactions were not considered biologically important. We conducted our a priori statistical tests on the decade $\times$ location interaction because it was significant in all models except the female protein model (Tables 2, 3). We specified those a priori two-tailed tests by the PDIFF option in the least-squares means statement of the decade $\times$ location interaction (PROC MIXED; SAS Institute 1993). We set the critical value for all a priori tests as $P \leq 0.05$, except for the Manitoba data set. We predicted a priori that there would be low power for comparisons in the Manitoba data set, because of small sample sizes in the 1980s (Table 1). Accordingly, we increased the critical $P$ value to 0.10 in that comparison to decrease the possibility of a type II error (Zar 1996).

\section{Results}

In the PCAs, all correlations between morphometrics were positive for each sex. Additionally, eigenvectors of PC1 ranged from 0.529 to 0.627 for females and 0.466 to 0.614 for males; PC1 accounted for $54 \%$ and $56 \%$ of variation in morphometrics of females and males, respectively.

We detected decade $\times$ location $(P<0.001)$ and collection day $\times$ location $(P<0.05)$ interactions 
TABle 2. Numerator $\mathrm{df}(\mathrm{N})$, denominator $\mathrm{df}(\mathrm{D})$, and $P$-values $(P)$ of fixed effects from final analyses of covariance models of each response variable (fresh body mass, lipid, protein, and mineral) for female Lesser Scaup collected during winter and spring migration in the Mississippi Flyway.

\begin{tabular}{|c|c|c|c|c|c|c|c|c|c|c|c|c|}
\hline \multirow[b]{2}{*}{ Effect } & \multicolumn{3}{|c|}{ Fresh body mass } & \multicolumn{3}{|c|}{ Lipid } & \multicolumn{3}{|c|}{ Protein } & \multicolumn{3}{|c|}{ Mineral } \\
\hline & $\mathrm{N}$ & $\mathrm{D}$ & $P$ & $\mathrm{~N}$ & $\mathrm{D}$ & $P$ & $\mathrm{~N}$ & $\mathrm{D}$ & $P$ & $\mathrm{~N}$ & $\mathrm{D}$ & $P$ \\
\hline $\mathrm{LOC}^{\mathrm{a}, \mathrm{b}}$ & 3 & 377 & 0.007 & 3 & 377 & $<0.001$ & 3 & 383 & $<0.001$ & 3 & 381 & $<0.001$ \\
\hline $\operatorname{DEC}^{c, d}$ & 1 & 6 & 0.305 & 1 & 6 & 0.152 & 1 & 7 & 0.139 & 1 & 6 & 0.740 \\
\hline PC1 b,e & 1 & 377 & $<0.001$ & 1 & 377 & $<0.001$ & 1 & 383 & $<0.001$ & 1 & 381 & $<0.001$ \\
\hline$C D^{b, f}$ & 1 & 377 & 0.566 & 1 & 377 & 0.358 & & & & & & \\
\hline $\mathrm{DEC} \times \mathrm{LOC}^{\mathrm{b}}$ & 3 & 377 & $<0.001$ & 3 & 377 & $<0.001$ & & & & 3 & 381 & $<0.001$ \\
\hline $\mathrm{CD} \times \mathrm{LOC}^{\mathrm{b}}$ & 3 & 377 & 0.046 & 3 & 377 & 0.017 & & & & & & \\
\hline
\end{tabular}

${ }^{a}$ Location (Louisiana, Illinois, Minnesota, and Manitoba).

${ }^{\mathrm{b}}$ Effect tested with model residual error term.

${ }^{c}$ Decade (1980s and 2000s).

${ }^{\mathrm{d}}$ Effect tested with year within decade error term.

${ }^{\mathrm{e}}$ First principal component of morphometrics.

${ }^{\mathrm{f}}$ Collection day adjusted for year and location (see text).

TABle 3. Numerator df $(\mathrm{N})$, denominator df (D), and $P$-values $(P)$ of fixed effects from final analyses of covariance models of each response variable (fresh body mass, lipid, protein, and mineral) for male Lesser Scaup collected during winter and spring migration in the Mississippi Flyway.

\begin{tabular}{|c|c|c|c|c|c|c|c|c|c|c|c|c|}
\hline \multirow[b]{2}{*}{ Effect } & \multicolumn{3}{|c|}{ Fresh body mass } & \multicolumn{3}{|c|}{ Lipid } & \multicolumn{3}{|c|}{ Protein } & \multicolumn{3}{|c|}{ Mineral } \\
\hline & $\mathrm{N}$ & $\mathrm{D}$ & $P$ & $\mathrm{~N}$ & $\mathrm{D}$ & $P$ & $\mathrm{~N}$ & $\mathrm{D}$ & $P$ & $\mathrm{~N}$ & $\mathrm{D}$ & $P$ \\
\hline $\mathrm{LOC}^{\mathrm{a}, \mathrm{b}}$ & 3 & 372 & $<0.001$ & 3 & 372 & $<0.001$ & 3 & 375 & $<0.001$ & 3 & 375 & 0.010 \\
\hline $\mathrm{DEC}^{\mathrm{c}, \mathrm{d}}$ & 1 & 5 & 0.037 & 1 & 5 & 0.006 & 1 & 5 & 0.820 & 1 & 5 & 0.028 \\
\hline PC $1^{b, e}$ & 1 & 372 & $<0.001$ & 1 & 372 & 0.044 & 1 & 375 & $<0.001$ & 1 & 375 & 0.002 \\
\hline$C D^{b, f}$ & 1 & 372 & 0.293 & 1 & 372 & 0.203 & 1 & 375 & 0.032 & 1 & 375 & 0.013 \\
\hline $\mathrm{DEC} \times \mathrm{LOC}^{\mathrm{b}}$ & 3 & 372 & $<0.001$ & 3 & 372 & $<0.001$ & 3 & 375 & 0.016 & 3 & 375 & 0.002 \\
\hline $\mathrm{CD} \times \mathrm{LOC}^{\mathrm{b}}$ & 3 & 372 & 0.011 & 3 & 372 & 0.014 & & & & & & \\
\hline
\end{tabular}

${ }^{a}$ Location (Louisiana, Illinois, Minnesota, and Manitoba).

${ }^{\mathrm{b}}$ Effect tested with model residual error term.

${ }^{c}$ Decade (1980s and 2000s).

d Effect tested with year within decade error term.

${ }^{\text {e }}$ First principal component of morphometrics.

${ }^{\text {f }}$ Collection day adjusted for year and location (see text).

for body mass and lipid reserves of females and males (Tables 2, 3). We also detected a decade $\times$ location interaction $(P<0.001)$ in mineral reserves of females (Table 2). The decade $\times$ location interaction was not present in final model for protein reserves of females, nor did protein reserves of females differ by decade (Table 2). However, for males, the decade $\times$ location interaction was detected in the protein reserves model (Table 3 ), but protein did not differ between decades, except in Manitoba.

Louisiana.-Mean body mass and lipid and mineral reserves of females were $80.0 \mathrm{~g}(12 \%)$, $52.5 \mathrm{~g}(52 \%)$, and $3.0 \mathrm{~g}(12 \%)$ greater, respectively, in the 2000s than in the 1980s, and those of males were $108.8 \mathrm{~g}(15 \%), 72.5 \mathrm{~g}(84 \%)$, and $2.4 \mathrm{~g}(8 \%)$ greater, respectively, in the same periods (Fig. 1).
Illinois. - Mean body mass and lipid reserves of females were $88.6 \mathrm{~g}(13 \%)$ and $56.5 \mathrm{~g}(51 \%)$ greater, respectively, in the 2000s than in the $1980 \mathrm{~s}$, and those of males were $80.6 \mathrm{~g}(10 \%)$ and $76.0 \mathrm{~g}(60 \%)$ greater, respectively, in the same periods (Fig. 1). Mean mineral reserves of males were $2.7 \mathrm{~g}(10 \%)$ greater in the $2000 \mathrm{~s}$ than those in the 1980s, whereas mean mineral reserves did not differ between decades for females (Fig. 1).

Minnesota.-Mean body mass was $58.5 \mathrm{~g}$ $(8 \%)$ and $40.7 \mathrm{~g}(5 \%)$ lower in the 2000s than in the 1980s for females and males, respectively (Fig. 1). Mean lipid reserves of females were $28.8 \mathrm{~g} \mathrm{(30 \% )}$ lower in the 2000s than in the $1980 \mathrm{~s}$ (Fig. 1). Mean mineral reserves did not differ between decades for either sex (Fig. 1).

Manitoba.-Mean body mass and lipid and 

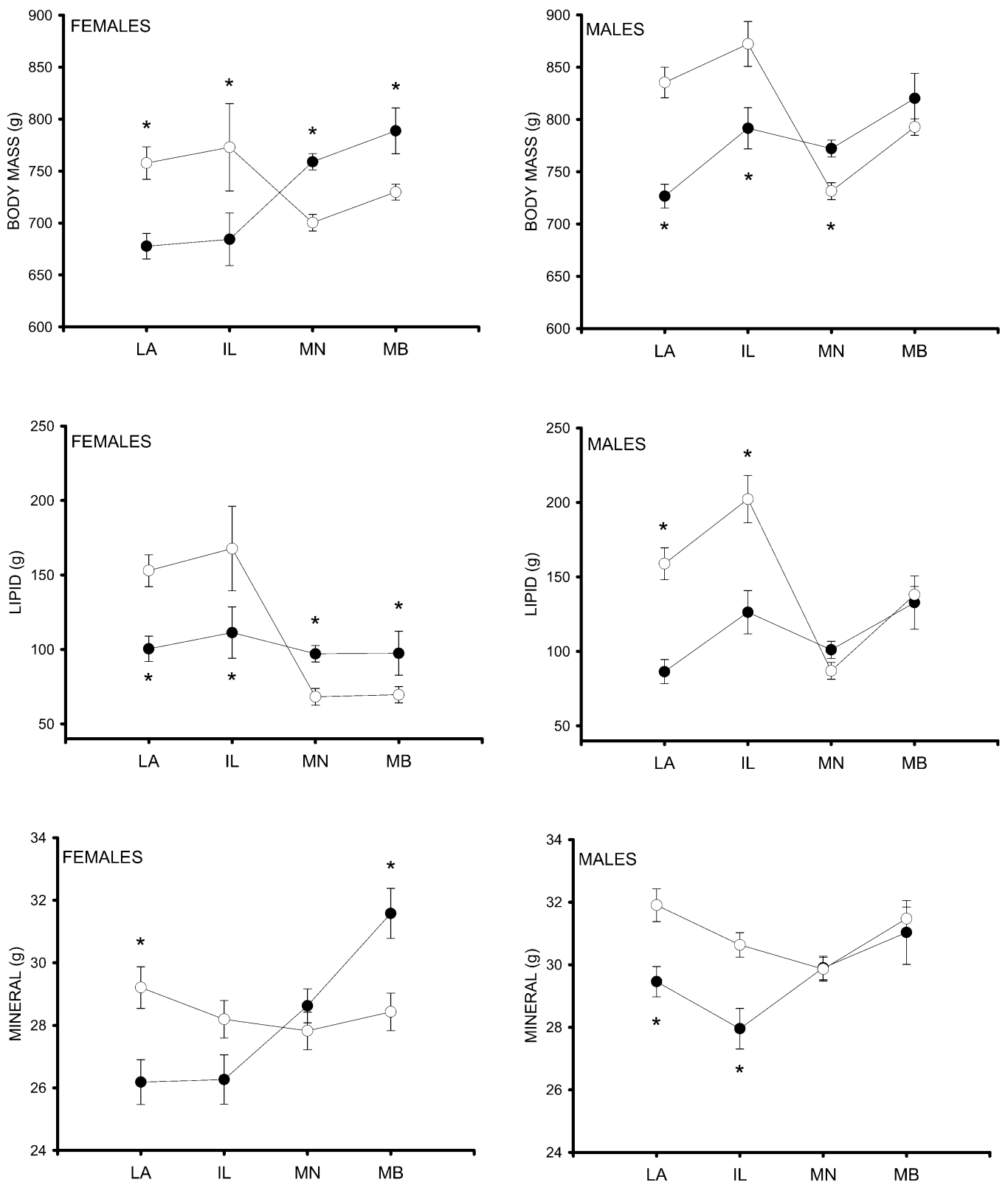

FIG. 1. Least-square means ( $\mathrm{g} \pm \mathrm{SE}$ ) of body mass and lipid and mineral reserves for female and male Lesser Scaup collected at four locations (southern Louisiana [LA], Pool 19, Illinois [IL], northwestern Minnesota [MN], and near Erickson, Manitoba [MB]) in the Mississippi Flyway during spring migration in the 1980s (filled circles) and 2000s (unfilled circles). Significant differences $(P<0.05$ [except MB, where $P<0.1$ ] $)$ between decades at given locations are indicated with an asterisk.

mineral reserves of females were $58.9 \mathrm{~g}(8 \%)$, $27.8 \mathrm{~g}(29 \%)$, and $3.2 \mathrm{~g}(10 \%)$ lower, respectively, in the 2000s than in the 1980s (Fig. 1). Mean protein reserves of males were $14.3 \mathrm{~g}(8 \%)$ lower in the 2000s than in the 1980s $(P=0.016)$.

\section{Discussion}

Louisiana.-We found that body mass and lipid and mineral reserves of both sexes were greater in the 2000s than in the 1980s; however, 
those results must be viewed with caution. Timing and locations of 1980s and 2000s collections in Louisiana differed (Table 1), and such differences could affect comparisons of body mass and nutrient reserves. We detected a collection day $\times$ location interaction in final models of body mass and lipid reserves for both sexes; however, collection day was not related to body mass or lipid-reserve levels for either sex in Louisiana. Those findings suggest that body mass and nutrient reserves of scaup do not change greatly during mid- to late winter in Louisiana. Thus, our comparisons of body mass and nutrient reserves by decade in Louisiana were confounded by potential differences in collection sites, but apparently were not biased by differences in collection dates between decades.

Illinois. - Body mass and lipid reserves were greater in the 2000s than in the 1980s in both sexes. We suspect that those observed increases in body mass and lipid reserves resulted from recent increases in availability or quality of scaup food on Pool 19 or preceding stopover and wintering areas. Abundance of fingernail clams (Musculium transversum), an important scaup food (Thompson 1973, Afton et al. 1991), declined markedly in the late 1980s on Pool 19 and probably at pools farther south (Wilson et al. 1995). However, fingernail clam abundance on Pool 19 generally is positively correlated with the mean hydraulic discharge of the previous spring (Wilson et al. 1995). We surmise that fingernail clams were abundant in 2000 and 2001, given that mean spring hydraulic discharge was relatively high from 1991 through 2001 (LaTour et al. 2001). Additionally, zebra mussels (Dreissena polymorpha), a known scaup food (Wormington and Leach 1992, Hamilton et al. 1994, Custer and Custer 1996), were first discovered in the upper Mississippi River in 1991 (Cope et al. 1997) and their abundance has increased markedly since 1995 (Sauer 2001).

Minnesota.-We documented significant decreases in body mass (8\%) and lipid reserves $(30 \%)$ of females from the 1980 s to the 2000s. Moreover, body mass and lipid reserves of females in Minnesota were lower than at any of the other locations in the 2000s, and lipd reserves were $99.6 \mathrm{~g}$ (59\%) lower than in Illinois. If our collection sites and preceding stopover areas through which scaup migrated had greatly different food-resource levels, we would expect to find large variations in body mass and lipid-reserve levels of scaup collected in Minnesota, because collected ducks probably included some individuals that had arrived recently as well as those that had been on collection sites for several days. However, we generally observed low levels of body mass and lipid reserves with little variation for both sexes in Minnesota, which suggests that there has been a landscape-scale decrease in food resources on stopover areas somewhere north of Illinois, including areas in northwestern Minnesota.

Manitoba.-On average, scaup eggs contain $6.8 \mathrm{~g}$ lipids and $4.1 \mathrm{~g}$ minerals (Afton and Ankney 1991). Accordingly, we found that female scaup arriving to breed in southwestern Manitoba had accumulated lipid reserves for 4.1 fewer eggs and mineral reserves for 0.8 fewer eggs in the 2000s than had those arriving there in the 1980s. That does not necessarily mean that females are laying 4.1 fewer eggs; rather, it illustrates the severity of the decrease in lipid and mineral reserves accumulated by females upon arrival.

In the 2000s, mean body mass and lipidreserve levels of females in Manitoba were low and varied little. We believe that body condition of females in that sample was primarily influenced by factors operating on preceding spring-migration stopover areas, because specimens were collected soon after their arrival in Manitoba. Furthermore, it is unlikely that all females collected in Manitoba had recently departed our specific Minnesota collection sites; consequently, whatever factors were causing declines in body condition must be affecting females on many stopover areas south of our Manitoba collection site. Those results, coupled with results from Minnesota, were consistent with the hypothesis that a landscape-scale decline in female body condition has occurred in the Mississippi Flyway.

Importance of northern spring-stopover areas.Heitmeyer (1988) suggested that wintering and southern spring-stopover areas were important for the accumulation of lipid reserves by Mallards (Anas platyrhynchos). Mallards on his collection sites were probably optimizing lipid storage by consuming large quantities of acorns and crustaceans, which are a good source of high-energy fatty acids capable of compact storage in the body (Heitmeyer and Fredrickson 1990). In contrast, Alisauskas (1988) demonstrated that Lesser Snow Geese (Chen caerulescens 
caerulescens) accumulated most of their lipid reserves for breeding at northern spring-stopover areas. Similarly, Gauthier et al. (1992) reported that prebreeding lipid accumulation in Greater Snow Geese (C. c. atlantica) began after they departed from wintering areas.

Scaup likely have higher wing-loading than Mallards or Lesser Snow Geese (Alisauskas and Ankney 1992, Lovvorn and Jones 1994). Accordingly, it may be advantageous for female scaup to accumulate lipid reserves for breeding later in migration to minimize migration and body-maintenance costs (see Alisauskas and Ankney 1992). However, lipid reserves of females in the 1980s appear similar among collection locations at different latitudes, possibly because their levels in the upper Midwest were already lower than levels prior to the start of the scaup population decline. Body mass of scaup migrating through the Klamath Basin in California during spring was similar to that in midwinter (Gammonley and Heitmeyer 1990), and below historical levels on arrival at a breeding area in southwestern Manitoba (Afton and Ankney 1991), which further suggests the importance of northern stopover areas for nutrientreserve accumulation in scaup. Moreover, body mass and lipid reserves of Greater and Lesser scaup at a northern stopover area in Quebec increased greatly between early and late spring (Chappell 1982). In conclusion, we believe that northern spring-stopover areas are important for accumulation and maintenance of lipid reserves used by breeding female scaup.

Spring condition hypothesis. - Esler et al. (2001) reported that female scaup with nondeveloped ovaries had smaller lipid and protein reserves than those that had initiated RFG, which is consistent with the hypothesis of a nutrient-reserve threshold that females must exceed before the initiation of RFG (Reynolds 1972). Accordingly, females arriving on breeding areas with small lipid and mineral reserves are probably unable to quickly exceed their nutrient-reserve threshold, and thus have decreased breeding propensity or must spend more time foraging on breeding areas prior to laying eggs (see Afton and Anderson 2001).

Scaup breeding near Erickson, Manitoba, initiated laying markedly later in 1999 and 2000 (Koons 2001, Koons and Rotella 2003), as compared with historical records from 1977 to 1980 (Afton 1984). Mean nest-initiation dates of scaup nesting near Yellow Knife, Northwest Territories, were 19 and 21 June in 1999 and 2000, respectively, whereas peak initiation dates (back-calculated from brood observations) at the same location ranged from 7 to 13 June during 1967-1970 (Brook 2002). Such delays in nest initiation by scaup are especially alarming, given that scaup are migrating through North Dakota earlier than they did historically (Austin et al. 2002), and some bird species are currently nesting $\leq 10$ days earlier because of global climatechange effects (Crick et al. 1997, Wuethrich 2000, Both and Visser 2001). Because nest success, duckling survival, and post-fledging survival are generally negatively correlated with nest initiation dates among northern-nesting waterfowl (Rohwer 1992, Dzus and Clark 1998, Guyn and Clark 1999, Blums et al. 2002) and clutch size of scaup declines seasonally (Afton 1984, Esler et al. 2001, Brook 2002), females, which arrive on breeding areas in poor bodycondition and subsequently breed, probably nest later (Reynolds 1972, Esler et al. 2001) and, concomitantly, produce relatively fewer young. Similarly, Alisauskas (2002) reported that body condition of Lesser Snow Geese in spring was positively related to age ratios (immature and adult) later that fall, further indicating that spring body-condition is an important determinant of recruitment.

Our results are consistent with the spring condition hypothesis (Afton and Anderson 2001), given the observed decadal decreases in body mass and lipid reserves of females during spring migration in Minnesota and decreases in body mass, lipids, and mineral reserves of females on arrival at a breeding area in Manitoba. Moreover, our results suggest that there has been a landscape-scale decline in female body condition on spring-stopover areas in the upper Midwest, which may affect body condition of females on arrival at other breeding areas. If females nesting in the boreal forest are arriving in poor body-condition, delays in nest initiation should have a greater effect on recruitment there than for those nesting in the Prairie Parklands, because less time is available between arrival and egg laying to acquire nutrients for breeding in the boreal forest (Austin et al. 1998, Afton and Anderson 2001). Notably, Afton and Anderson (2001) reported that the steepest scaup population declines have occurred in the boreal forest. 
Our findings that body mass of males in both Minnesota and Manitoba have decreased from historical numbers supports the spring condition hypothesis. However, a decline in body condition of males is not required under the spring condition hypothesis (Afton and Anderson 2001). Interestingly, we did not detect major decadal differences in nutrient reserves of males in Minnesota and Manitoba. Thus, behavioral or physiological differences may exist between sexes (e.g. feeding rates, pairing behavior, molt, metabolism, and body size) that affect accumulation of nutrient reserves during spring migration. An understanding of mechanisms that affect apparent differential accumulation of nutrient reserves between sexes is important for better understanding nutrient-reserve dynamics of scaup during spring migration and, in turn, may provide a better understanding of mechanisms affecting decreases in body condition of females.

Body mass and nutrient reserves of migrating scaup are probably influenced by environmental factors at our collection sites and those on preceding stopover areas. Considering spring migration routes and the current poor body-condition of scaup in Minnesota and Manitoba, we argue that any future decline in food resources at Pool 19, as occurred from 1985 to 1991 (Wilson et al. 1995, Havera 1999), would cause even further decreases in body condition in Minnesota and Manitoba.

We believe that the most likely and parsimonious explanation for the observed decrease in female body condition after departure from Illinois is reduced availability or quality of food resources (or both) on spring stopover areas in the upper Midwest. Possible factors affecting availability and quality of scaup food resources in the upper Midwest include (1) loss of semipermanent and permanent wetlands, which scaup use during spring migration (Korschgen 1989, Austin et al. 1998); (2) a landscape-scale increase in numbers or foraging effectiveness of fish or other macroinvertebrate predators (e.g. salamanders; see below); (3) an increase in anthropogenic sedimentation (reviewed by Gleason and Euliss 1998, Anteau 2002); (4) an increase in agricultural chemicals leached into wetlands (Neely and Baker 1989, Tome et al. 1995); and (5) global climate-change effects (e.g. changes in winter kill frequency, snowfall patterns, and water depths; Poiani and Johnson 1991, Sweeney et al. 1992, Sorenson et al. 1998).
Scaup consume macroinvertebrates almost exclusively in spring, and amphipods were historically their single most important food during spring and summer throughout the upper Midwest (Rogers and Korschgen 1966, Swanson and Nelson 1970, Swanson and Duebbert 1989, Afton and Hier 1991, Afton et al. 1991). Densities of amphipods and other food items affect scaup use of particular wetlands in spring, summer, and fall (Afton et al. 1991, Hanson and Butler 1994, Lindeman and Clark 1999). Therefore, we deduce that (1) scaup probably spend little time on wetlands that have poor forage resources while they move across the landscape during spring migration and (2) body condition of scaup is probably influenced mostly by factors on preceding stopover areas when they are collected from areas with poor forage conditions. Accordingly, we argue that landscape-scale declines in amphipods or other preferred foods (or both) are required to cause the observed declines in scaup body condition during spring migration.

Natural invasions or introductions of minnows (including fathead minnows [Pimephales promelas]) and other aquaculture practices (i.e. rearing and stocking of walleye [Stizostedion vitreum] and other game fish) have increased recently in semipermanent and permanent wetlands in the upper Midwest (Hanson and Riggs 1995, Bouffard and Hanson 1997). Moreover, roadside ditches, culverts, underground tile systems, and wetland drainage canals have increased connectivity of semipermanent and permanent wetlands and further facilitated invasions of fish into historically fish-free wetlands (Zimmer et al. 2000, 2001a). Fish decrease abundance, biomass, and size of amphipods and other important scaup foods directly through predation and indirectly by causing dramatic changes in trophic structure of wetlands (Wellborn 1994; Hanson and Riggs 1995; Bouffard and Hanson 1997; Duffy 1998; Zimmer et al. 2001a, 2001b). Thus, fish invasions or introductions into historically fish-free wetlands have potential to reduce availability and quality of scaup food resources across a large landscape.

Other possible factors affecting the observed decrease in female body condition include (1) increases in human disturbances that reduce foraging time or increase flight energy expenditures (Korschgen et al. 1985, Kahl 1991), (2) increased occurrence of disease (Goldberg et al. 1995, 
Augspurger et al. 2003), (3) increases in environmental contaminants (Custer et al. 2003), and (4) increased incidence of parasitism (Vest 2002, Haukos and Neaville 2003). Further research is needed to determine the rate at which all of those occur and to test their effects on body condition of scaup during spring migration.

Implications for conservation. - If conservation of scaup is a priority, we believe that efforts to stop the loss and degradation of wetlands and increase availability of important scaup foods (e.g. amphipods) at spring stopover areas in the upper Midwest would be helpful in reversing the population decline. Furthermore, a number of research questions need to be answered to provide more effective habitat management for scaup during spring migration in the upper Midwest: (1) In what geographic areas do females exhibit poor body condition (Iowa, North and South Dakota, and other parts of Minnesota)? (2) Are females able to procure historically preferred forage in those areas? (3) What specific factors are affecting the availability and quality of scaup foods across that landscape? and (4) How does body condition affect timing and rates of movement across the landscape during spring migration?

\section{Acknowledgments}

We thank J. H. Caswell, R. S. Durham, P. M. Dummer, A. P. Langlinais, B. C. Muller, K. D. Richkus, S. Talley, C. M. Tricou, and W. B. Wilson for assisting with collections and dissections. We are grateful for logistical support provided by R. V. Anderson, C. M. Custer, J. R. Fisher, R. N. Helm, S. P. Havera, T. J. Hess, J. D. Huener, T. C. Michot, F. C. Rohwer, and P. B. Telander. We thank the Muscle Foods Laboratory at Louisiana State University; Louisiana Universities Marine Consortium; Minnesota Department of Natural Resources; U.S. Geological Survey (USGS) National Wetland Research Center; Rockefeller State Wildlife Refuge; USGS Upper Midwest Environmental Sciences Center; Western Illinois University; Tri-Tronics Training Collars; and Federal, Winchester, Estate, and Kent Cartridge companies for in-kind support. The Louisiana State University Institutional Animal Care and Use Committee approved our experimental protocol (number 00-011). We gratefully acknowledge M. Anderson, M. G. Anderson, A. C. E. Anteau, F. Bolduc, E. F. Bowers, R. H. Hier, S. Kufrin, C. T. Pollet, and S. D. Wilds for their help and support of the project. We thank the following organizations for financial support: Delta Waterfowl Foundation, Institute for Wetland and Waterfowl Research (IWWR) of Ducks Unlimited
Canada, IWWR of Ducks Unlimited USA under the Edward D. and Sally Futch Fellowship program, Louisiana Department of Wildlife and Fisheries, U.S. Fish and Wildlife Service Regions 3 and 4, USGSLouisiana Cooperative Fish and Wildlife Research Unit, School of Renewable Natural Resources, and the Graduate School at Louisiana State University. Finally, we thank C. D. Ankney, J. A. Collazo, R. R. Cox, Jr., D. Esler, J. M. Fernandez, J. P. Geaghan, M. A. Hanson, G. Herring, J. R. Jehl Jr., R. M. Kaminski, D. A. Haukos, and two anonymous reviewers for providing helpful comments on the manuscript.

\section{Literature Cited}

Afton, A. D. 1984. Influence of age and time on reproductive performance of female Lesser Scaup. Auk 101:255-265.

Afton, A. D. 1985. Forced copulation as a reproductive strategy of male Lesser Scaup: A field test of some predictions. Behaviour 92: 146-167.

Afton, A. D., And M. G. Anderson. 2001. Declining scaup populations: A retrospective analysis of long-term population and harvest survey data. Journal of Wildlife Management 65:781-796.

Afton, A. D., And C. D. Ankney. 1991. Nutrientreserve dynamics of breeding Lesser Scaup: A test of competing hypotheses. Condor 93: 89-97.

Afton, A. D., And R. H. Hier. 1985. Fall migration ecology of Lesser Scaup in Minnesota. Pages 74-94 in Wildlife Research Unit 1985 Report. Minnesota Department of Natural Resources, St. Paul.

Afton, A.D., And R. H. Hier. 1991. Diets of Lesser Scaup breeding in Manitoba. Journal of Field Ornithology 62:325-334.

Afton, A. D., R. H. Hier, and S. L. Paulus. 1989. Nutrient reserves of Lesser Scaup in midwinter in southwestern Louisiana. Proceedings of the Annual Conference of the Southeastern Association of Fish Wildlife Agencies 43: 404-411.

Afton, A. D., R. H. Hier, and S. L. Paulus. 1991. Lesser Scaup diets during migration and winter in the Mississippi Flyway. Canadian Journal of Zoology 69:328-333.

Afton, A. D., And S. L. Paulus. 1992. Incubation and brood care. Pages 62-108 in Ecology and Management of Breeding Waterfowl (B. D. J. Batt, A. D. Afton, M. G. Anderson, C. D. Ankney, D. H. Johnson, J. A. Kadlec, and G. L. Krapu, Eds.). University of Minnesota Press, Minneapolis.

Alisauskas, R. T. 1988. Nutrient reserves of Lesser Snow Geese during winter and spring migration. Ph.D. dissertation, University of Western Ontario, London. 
Alisauskas, R. T. 2002. Arctic climate, spring nutrition, and recruitment of midcontinent Lesser Snow Geese. Journal of Wildlife Management 66:181-193.

Alisauskas, R. T., And C. D. Ankney. 1992. The cost of egg laying and its relationship to nutrient reserves in waterfowl. Pages 30-61 in Ecology and Management of Breeding Waterfowl (B. D. J. Batt, A. D. Afton, M. G. Anderson, C. D. Ankney, D. H. Johnson, J. A. Kadlec, and G. L. Krapu, Eds.). University of Minnesota Press, Minneapolis.

Anteau, M. J. 2002. Nutrient reserves of Lesser Scaup during spring migration in the Mississippi Flyway: A test of the spring condition hypothesis. M.S. thesis, Louisiana State University, Baton Rouge.

Augspurger, T., J. R. Fischer, N. J. Thomas, L. Sileo, R. E. Brannian, K. J. G. Miller, and T. E. Rocke. 2003. Vacuolar myelinopathy in waterfowl from a North Carolina impoundment. Journal of Wildlife Diseases 39:412-417.

Austin, J. E., A. D. Afton, M. G. Anderson, R. G. Clark, C. M. Custer, J. S. Lawrence, J. B. Pollard, and J. K. Ringelman. 2000. Declining scaup populations: Issues, hypotheses, and research needs. Wildlife Society Bulletin 28: 254-263.

Austin, J. E., C. M. Custer, and A. D. Afton. 1998. Lesser Scaup (Aythya affinis). In The Birds of North America, no. 338 (A. Poole and F. Gill, Eds.). Academy of Natural Sciences, Philadelphia, and American Ornithologists' Union, Washington, D.C.

Austin, J. E., D. G. Granfors, M. A. Anderson, AND S. C. KoHn. 2002. Scaup migration patterns in North Dakota relative to temperatures and water conditions. Journal of Wildlife Management 66:874-882.

Blums, P., R. G. Clark, and A. Mednis. 2002. Patterns of reproductive effort and success in birds: Path analyses of long-term data from European ducks. Journal of Animal Ecology 71:280-295.

Both, C., AND M. E. Visser. 2001. Adjustment to climate change is constrained by arrival date in a long-distance migrant bird. Nature 411:296-298.

Bouffard, S. H., And M. A. Hanson. 1997. Fish in waterfowl marshes: Waterfowl manager's perspective. Wildlife Society Bulletin 25:146-157.

Brook, R. W. 2002. Breeding ecology and local population dynamics of Lesser Scaup (Aythya affinis) in boreal forest of western Canada. M.S. thesis, University of Saskatchewan, Saskatoon.

Carney, S. M. 1992. Species, Age and Sex Identification of Ducks Using Wing Plumage. U.S. Department of the Interior, Fish and Wildlife Service, Washington, D.C.
Chappell, W. A. 1982. Aspects of the energetics of Greater Scaup (Aythya marila) and Lesser Scaup (A. affinis) during migration. M.S. thesis, McGill University, Montreal, Quebec.

Cope, W. G., M. R. Bartsch, and R. R. Hayden. 1997. Longitudinal patterns in abundance of the zebra mussel (Dreissena polymorpha) in the Upper Mississippi River. Journal of Freshwater Ecology 12:235-238.

Crick, H. Q. P., C. Dudley, D. E. Glue, and D. L. Thomson. 1997. UK birds are laying eggs earlier. Nature 388:526.

Custer, C. M., and T. W. Custer. 1996. Food habits of diving ducks in the Great Lakes after the zebra mussel invasion. Journal of Field Ornithology 67:86-99.

Custer, C. M., T. W. Custer, M. J. Anteau, A. D. Afton, And D. E. Wooten. 2003. Trace elements in Lesser Scaup (Aythya affinis) from the Mississippi Flyway. Ecotoxicology 12:47-54.

Duffy, W. G. 1998. Population dynamics, production, and prey consumption of fathead minnows (Pimephales promelas) in prairie wetlands: A bioenergetics approach. Canadian Journal of Fisheries and Aquatic Sciences 54:15-27.

Dzus, E. H., And R. G. Clark. 1998. Brood survival and recruitment of Mallards in relation to wetland density and hatching date. Auk 115: 311-318.

Esler, D., J. B. Grand, and A. D. Afton. 2001. Intraspecific variation in nutrient reserve use during clutch formation by Lesser Scaup. Condor 130:810-820.

Gammonley, J. H., and M. E. Heitmeyer. 1990. Behavior, body condition, and foods of Buffleheads and Lesser Scaups during spring migration though the Klamath Basin, California. Wilson Bulletin 102:672-683.

Gauthier, G., J.-F. Giroux, And J. Bédard. 1992. Dynamics of fat and protein reserves during winter and spring migration in Greater Snow Geese. Canadian Journal of Zoology 70: 2077-2087.

Gleason, R. A., AND N. H. Euliss, JR. 1998. Sedimentation of prairie wetlands. Great Plains Research 8:97-112.

Goldberg, D. R., M. D. Samuel, C. B. Thomas, P. Sharp, G. L. Krapu, J. R. Robb, K. P. Kenow, C. E. Korschgen, W. H. Chipley, M. J. Conroy, and S. H. Kleven. 1995. The occurrence of mycoplasmas in selected wild North American waterfowl. Journal of Wildlife Diseases 31:364-371.

Guyn, K. L., and R. G. Clark. 1999. Factors affecting survival of Northern Pintail ducklings in Alberta. Condor 101:369-377.

Hamilton, D. J., C. D. Ankney, and R. C. Bailey. 1994. Predation of zebra mussels by diving ducks: An exclosure study. Ecology 75:521-531. 
Hanson, M. A., And M. G. Butler. 1994. Response of food web manipulation in a shallow waterfowl lake. Hydrobiologia 279/280:457-466.

Hanson, M. A., And M. R. Riggs. 1995. Potential effects of fish predation on wetland invertebrates: A comparison of wetlands with and without fathead minnows. Wetlands 15: 167-175.

HaVera, S. P. 1999. Waterfowl of Illinois: Status and Management. Phoenix Publishing, Urbana, Illinois.

Haukos, D. A., and J. Neaville. 2003. Spatial and temporal changes in prevalence of a cloacal cestode in wintering waterfowl along the gulf coast of Texas. Journal of Wildlife Diseases 39: 152-160.

Heitmeyer, M. E. 1988. Body composition of female Mallards in winter in relation to annual cycle events. Condor 90:669-680.

Heitmeyer, M. E., and L. H. Fredrickson. 1990. Fatty acid composition of wintering female Mallards in relation to nutrient use. Journal of Wildlife Management 54:54-61.

Hohman, W. L. 1985. Feeding ecology of RingNecked Ducks in northwestern Minnesota. Journal of Wildlife Management 49:546-557.

KAHL, R. 1991. Boating disturbance of Canvasbacks during migration at Lake Poygan, Wisconsin. Wildlife Society Bulletin 19:242-249.

Koons, D. N. 2001. Lesser Scaup breeding ecology in the Canadian parklands. M.S. thesis, Montana State University, Bozeman.

Koons, D. N., And J. J. Rotella. 2003. Comparative nesting success of sympatric Lesser Scaup and Ring-Necked Ducks. Journal of Field Ornithology 74:222-229.

Korschgen, C. E. 1989. Riverine and deepwater habitats for diving ducks. Pages 157-180 in Habitat Management for Migrating and Wintering Waterfowl in North America (L. M. Smith, R. L. Pederson, and R. M. Kaminski, Eds.). Texas Tech University Press, Lubbock.

Korschgen, C. E., L. S. George, and W. L. Green. 1985. Disturbance of diving ducks by boaters on a migrational staging area. Wildlife Society Bulletin 13:290-296.

LaTour, J. K., J. M. Gioja, J. C. Maurer, and T. L. WiCKer. 2001. Water resources data, Illinois, water year 2000. U.S. Geological Survey WaterData Annual Report IL-00.

Lindeman, D. H., AND R. G. Clark. 1999. Amphipods, land-use impacts, and Lesser Scaup (Aythya affinis) distribution in Saskatchewan wetlands. Wetlands 19:627-638.

Lovvorn, J. R., AND D. R. JonEs. 1994. Biomechanical conflicts between adaptations for diving and aerial flight in estuarine birds. Estuaries 17:62-75.

NeEly, R. K., AND J. L. BAKer. 1989. Nitrogen and phosphorus dynamics and the fate of agricultural runoff. Pages 92-131 in Northern Prairie Wetlands (A. G. van der Valk, Ed.). Iowa State University Press, Ames.

Pace, R. M., III, And A. D. Afton. 1999. Direct recovery rates of Lesser Scaup banded in northwest Minnesota: Sources of heterogeneity. Journal of Wildlife Management 63:389-395.

Poinni, K. A., And W. C. Johnson. 1991. Global warming and prairie wetlands: Potential consequences for waterfowl management. BioScience 41:611-618.

Reynolds, C. M. 1972. Mute Swan weights in relation to breeding. Wildfowl 23:111-118.

Rogers, J. P. 1964. Effect of drought on reproduction of Lesser Scaup. Journal of Wildlife Management 28:213-222.

Rogers, J. P., And L. J. Korschgen. 1966. Foods of Lesser Scaups on breeding, migration, and wintering areas. Journal of Wildlife Management 30:258-264.

Rohwer, F. C. 1992. The evolution of reproductive patterns in waterfowl. Pages 486-539 in Ecology and Management of Breeding Waterfowl (B. D. J. Batt, A. D. Afton, M. G. Anderson, C. D. Ankney, D. H. Johnson, J. A. Kadlec, and G. L. Krapu, Eds.). University of Minnesota Press, Minneapolis.

Ryder, J. P. 1970. A possible factor in the evolution of clutch size in Ross's Goose. Wilson Bulletin 82:5-13.

SAS Institute. 1993. SAS/STAT User's Guide, version 6, 4th ed. SAS Institute, Cary, North Carolina.

SAUER, J. 2001. Macroinvertebrate sampling in six reaches of the Upper Mississippi River System, 2000. U.S. Geological Survey, Upper Midwest Environmental Sciences Center, La Crosse, Wisconsin.

Sorenson, L. G., R. Goldberg, T. L. Root, and M. G. Anderson. 1998. Potential effects of global warming on waterfowl populations breeding in the Northern Great Plains. Climatic Change 40:343-369.

Swanson, G. A., and H. F. Duebbert. 1989. Wetland habitats of waterfowl in the Prairie Pothole Region. Pages 228-267 in Northern Prairie Wetlands (A. G. van der Valk, Ed.). Iowa State University Press, Ames.

Swanson, G. A., And H. Nelson. 1970. Potential influence of fish rearing programs on waterfowl breeding habitat. Pages 65-71 in Symposium on the Management of Midwestern Winterkill Lakes (E. Schneberger, Ed.). North Central Division of the American Fisheries Society, Winnipeg, Manitoba.

Sweeney, B. W., J. K. Jackson, J. D. Newbold, and D. H. FunK. 1992. Climate change and the life 
histories and biogeography of aquatic insects in eastern North America. Pages 143-176 in Global Climate Change and Freshwater Ecosystems (P. Firth and S. G. Fisher, Eds.). Springer-Verlag, New York.

Thompson, D. 1973. Feeding ecology of diving ducks on Keokuk Pool, Mississippi River. Journal of Wildlife Management 37:382-389.

Tome, M. W., C. E. Grue, and M. G. Henry. 1995. Case studies: Effects of agricultural pesticides on waterfowl and Prairie Pothole wetlands. Pages 565-576 in Handbook of Ecotoxicology (D. J. Hoffman, B. A. Rattner, G. A. Burton, Jr., and J. Cairns, Jr., Eds.). Lewis Publishers, CRC Press, Boca Raton, Florida.

Vest, J. L. 2002. Body mass and gastrointestinal parasites in Lesser Scaup (Aythya affinis) in the Mississippi Flyway. M.S. thesis, Mississippi State University, Starkville.

Wellborn, G. A. 1994. Size-biased predation and prey life-histories-A comparative study of fresh-water amphipod populations. Ecology 75:2104-2117.

Wilkins, K. A., and M. C. Отto. 2003. Trends in duck breeding populations, 1955-2003. U.S. Department of the Interior, Fish and Wildlife Service, Laurel, Maryland.

Willson, D. M., T. J. Naimo, J. G. Wiener, R. V. Anderson, M. B. SAndheirich, AND R.
E. Sparks. 1995. Declining populations of fingernail clam Musculium transversum in the upper Mississippi River. Hydrobiologia 304: 209-220.

Wormington, A., AND J. H. Leach. 1992. Concentrations of migrant diving ducks at Point Pelee National Park, Ontario, in response to invasions of zebra mussels, Dreissena polymorpha. Canadian Field-Naturalist 106:376-380.

Wuethrich, B. 2000. How climate change alters rhythms of the wild. Science 287:793-795.

ZAR, J. H. 1996. Biostatisical Analysis, 3rd ed. Prentice-Hall, Upper Saddle River, New Jersey.

Zimmer, K. D., M. A. Hanson, and M. G. Butler. 2000. Factors influencing invertebrate communities in prairie wetlands: A multivariate approach. Canadian Journal of Fisheries and Aquatic Sciences 57:76-85.

Zimmer, K. D., M. A. Hanson, and M. G. Butler. 2001a. Effects of fathead minnow colonization and removal on a prairie wetland ecosystem. Ecosystems 4:346-357.

Zimmer, K. D., M. A. Hanson, M. G. Butler, AND W. G. Duffy. 2001b. Size distribution of aquatic invertebrates in two prairie wetlands, with and without fish, with implications for community production. Freshwater Biology 46:1373-1386.

Associate Editor: D. A. Haukos 